\title{
KINERJA LINGKUNGAN DAN KINERJA SAHAM PERUSAHAAN PUBLIK DI INDONESIA
}

\author{
ENVIRONMENTAL AND STOCK PERFORMANCE OF PUBLIC COMPANIES IN INDONESIA
}

\author{
Negina Kencono Putri* ${ }^{* 1}$ dan Estri Mufridatul Hikmah ${ }^{*}$ \\ *) Jurusan Akuntansi Fakultas Ekonomi dan Bisnis Universitas Jenderal Soedirman \\ Jl. Prof. Dr. H.R. Boenyamin No.708 Grendeng Purwokerto, 53122
}

\begin{abstract}
Environmental performance carried out by the company can be an indicator of how well the company carries out the level of environmental management. This study aimed to examine the effect of environmental performance on the stock performance of public companies listed in the SRI KEHATI index in the Indonesia Stock Exchange. The samples consisted of 22 companies listed on the Indonesia Stock Exchange and included in the index during 2017-2019. Environmental performance is measured through environmental performance reporting that refers to the Global Reporting Initiative (GRI) standard Series 300. The standard consists of 8 components. Meanwhile, stock performance is measured by the value of Cumulative Abnormal Return (CAR). The data were processed using regression after testing the classical assumptions previously. The results showed that companies with a good stock performance report had a good environmental performance, as indicated by the t-test value, which all had a positive direction. Besides, the components of energy, biology, waste, and environmental compliance had statistically significant effects. This research implied that companies and investors need to pay attention to the efforts to submit environmental performance following the standards because it is proven to be able to influence firm value through its stock performance.
\end{abstract}

Keywords: sustainability reporting, company value, GRI standard Series 300, CAR, company performance

\begin{abstract}
Abstrak: Kinerja lingkungan yang dilaksanakan oleh perusahaan dapat menjadi salah satu indikator seberapa baik tingkat pengelolaan lingkungan yang dilakukan oleh perusahaan. Penelitian ini bertujuan menguji pengaruh kinerja lingkungan terhadap kinerja saham perusahaan publik yang terdaftar di Indeks SRI KEHATI di Bursa Efek Indonesia. Sampel terdiri dari 22 perusahaan yang terdaftar pada indeks tersebut di Bursa Efek Indonesia dan berturut-turut masuk ke dalam peringkat indeks tersebut selama tahun 2017-2019. Kinerja lingkungan diukur melalui pelaporan kinerja lingkungan yang mengacu pada standar Global Reporting Intitiative (GRI) Seri 300. Sementara, kinerja saham diukur melalui nilai Cummulative Abnormal Return (CAR) saham rata-rata pada tanggal penerbitan laporan kinerja lingkungan. Data diolah dengan menggunakan regresi setelah sebelumnya dilakukan pengujian asumsi klasik. Hasil penelitian menunjukkan bahwa perusahaan yang memiliki kinerja saham yang baik melakukan pelaporan kinerja lingkungan yang baik pula. Hal tersebut ditunjukkan dari nilai uji t yang seluruhnya memiliki arah positif. Selain itu, komponen energi, hayati, limbah dan kepatuhan lingkungan memiliki pengaruh yang secara statistik signifikan. Implikasi dari penelitian ini adalah agar perusahaan maupun investor memberikan porsi perhatian berupa usaha penyampaian laporan kinerja lingkungan yang disesuaikan dengan standar yang berlaku karena terbukti mampu mempengaruhi nilai perusahaan melalui kinerja sahamnya.
\end{abstract}

Kata kunci: sustainability reporting, nilai perusahaan, standard GRI Seri 300, CAR, kinerja perusahaan

\footnotetext{
${ }^{1}$ Alamat Korespondensi:

Email: negina.putri@unsoed.ac.id
} 


\section{PENDAHULUAN}

Tata kelola perusahaan yang baik merupakan salah satu elemen kunci dalam perusahaan yang melibatkan peran pemangku kepentingan. Kerangka tata kelola perusahaan yang baik harus mengakui hak-hak pemangku kepentingan, sebagaimana ditetapkan oleh hukum, dan mendorong kerja sama dalam menciptakan perusahaan yang sehat. Perusahaan publik memiliki kewajiban untuk melakukan pengungkapan terkait kinerja yang telah dilakukan. Pengungkapan kinerja tersebut diantaranya adalah pengungkapan dalam hal keuangan maupun non-keuangan. Pengungkapan keuangan disampaikan dalam bentuk laporan keuangan yang sesuai dengan standar yang berlaku dan peraturan yang terdapat pada otoritas bursa. Sementara, pengungkapan non-keuangan dapat berupa pengungkapan tambahan yang terkait dengan aktivitas perusahaan, yang salah satunya adalah pengungkapan lingkungan. Di Indonesia, pengungkapan terkait dengan kinerja lingkungan sebuah perusahaan belum menjadi hal yang bersifat wajib. Oleh karena, itu, perusahaan yang melakukan pelaporan kinerja lingkungan seringkali menggunakan standar yang dikeluarkan oleh Global Reporting Initiative (GRI).

Pengungkapan kinerja finansial serta non-finansial yang dilakukan oleh perusahaan secara terstruktur dan kontinyudapatmenunjukkantatakelolaperusahaantelah dilakukan dengan baik. Kerangka tata kelola perusahaan memastikan pengungkapan yang dilakukan tepat waktu dan akurat dari semua materi yang berhubungan dengan korporasi, termasuk masalah yang terkait dengan pemangku kepentingan lainnya. Perusahaan tidak hanya memiliki kewajiban untuk bertindak secara bertanggung jawab terhadap pemangku kepentingan tetapi juga untuk mengungkapkan tindakannya kepada para pemangku kepentingan. Alasan lain meningkatnya perhatian terhadap masalah ini adalah karena kurangnya tata kelola perusahaan yang baik, yang merupakan salah satu penyebab krisis keuangan (Cai et al. 2016). Salah satu bentuk tanggung jawab perusahaan adalah mengungkapkan laporan kinerja lingkungan kepada para pemangku kepentingan. Laporan kinerja lingkungan menjadi salah satu elemen penting dalam pelaporan yang terintegrasi dengan laporan keuangan. Beberapa penelitian menunjukkan adanya relasi antara laporan kinerja kuangan yang tertuang dalam laporan keuangan serta laporan kinerja lingkungan terhadap kinerja saham perusahaan (Chen et al. 2014; Chen et al. 2015; Connelly dan Limpaphayom, 2004).
Penelitian tentang hubungan antara kinerja lingkungan dan kinerja keuangan menunjukkan hasil yang saling bertentangan satu sama lain. Kepatuhan lingkungan seringkali dianggap sebagai hal yang mahal dan berpotensi untuk mengurangi keuntungan perusahaan. Oleh karena itu, dengan motif mengambil keuntungan, perusahaan akan memilih untuk berinvestasi sesedikit mungkin dalam kepatuhan lingkungan sehingga dapat memenuhi standar minimum yang disyaratkan secara hukum. Kinerja lingkungan dianggap berhubungan negatif dengan kinerja keuangan, dimana semakin banyak perusahaan yang memiliki kinerja keuangan yang baik akan menghabiskan lebih sedikit pengeluaran atau biaya untuk pengendalian lingkungan (Chen et al. 2014; Connelly dan Limpaphayom, 2004; Matsumura et al. 2014).

Perdebatan seputar biaya kepatuhan versus daya saing telah berubah, sebagaimana dicatat oleh beberapa penelitian (Chen et al. 2015; Comyns, 2016; Elsayed, 2006). Perusahaan yang secara efektif dapat mengurangi polusi dapat melakukannya menjadi lebih efisien dalam metode produksinya, sehingga menjamin keunggulan biaya dibandingkan dengan pesaing mereka yang tidak melakukan pengurangan polusi, sehingga perusahaan yang peduli terhadap lingkungan lebih menghasilkan keuntungan yang superior (Chen et al. 2015; Comyns, 2016; Elsayed, 2006; Huang dan Kung, 2010; Perez-Batres et al. 2010). Gagasan ini muncul karena perusahaan mengalihkan fokus dan menuju desain ulang metode produksi sehingga sumber polusi diminimalkan atau dihilangkan. Perusahaan yang memiliki lebih banyak keuntungan memiliki lebih banyak uang untuk dibelanjakan dalam upaya pengendalian lingkungan daripada pesaing mereka yang kurang menguntungkan.

Beberapa peneliti (Tschopp dan Huefner, 2015; Vigneau et al. 2015) membahas apakah 'investasi hijau' menghasilkan keuntungan yang lebih besar dibandingkan dengan strategi investasi netral. Hasil riset menunjukkan kehati-hatian dalam menampilkan arah hubungan antara kinerja keuangan dan kinerja lingkungan. Kesimpulan bahwa perusahaan yang menguntungkan lebih bertanggung jawab terhadap lingkungan karena mereka memiliki kinerja keuangan yang unggul akan lebih bijaksana dibandingkan kesimpulan bahwa perusahaan dapat meningkatkan keuangan kinerja dengan meningkatkan tanggung jawab lingkungan. Elsayed (2006) mengajukan hipotesis bahwa kinerja lingkungan dan kinerja keuangan 
terkait secara positif dengan pertumbuhan industri sebagai pemoderasinya. Mereka mengusulkan model dari perspektif berbasis sumber daya. Dalam studi Shaukat et al. (2016), peringkat lingkungan perusahaan yang teliti dan menjadi sampel, yang disediakan oleh organisasi independen, terdiri dari berbagai kriteria. Berbagai variabel kontrol (tingkat pertumbuhan, ukuran perusahaan, modal dan intensitas periklanan, dan beberapa karakteristik industri lainnya) juga menjadi pertimbangan. Peneliti menemukan hubungan positif antara kinerja perusahaan, yang diukur dengan pengembalian aset, dengan peringkat lingkungan. Tingkat pertumbuhan industri juga menjadi pemoderasi yang signifikan.

Sejumlah studi mendokumentasikan adanya hubungan negatif antara kinerja lingkungan dan kinerja keuangan (Matsumura et al. 2014; Willis, 2003). Peneliti menyimpulkan bahwa karakteristik tetap perusahaan (seperti ukuran perusahaan serta intensitas penelitian dan pengembangan riset dan pengembangan) menyebabkan hubungan negatif tersebut. Peneliti juga mendokumentasikan bahwa reaksi harga berpengaruh negatif atas pengumuman strategi pemasaran hijau. Peneliti menemukan, dari review literatur, bahwa konsumen sering dibuat bingung dengan upaya promosi perusahaan, yang pada akhirnya menyebabkan efek negatif pada harga saham. Namun, pengumuman produk ramah lingkungan, upaya daur ulang, dan penunjukan pengelola lingkungan menghasilkan reaksi harga saham yang tidak signifikan. Seperti beberapa studi kasus juga menemukan bahwa ukuran perusahaan memoderasi hubungan tersebut (Kathy Rao et al. 2012; Nurhayati et al. 2016).

Hubungan antara kepatuhan lingkungan dan atau pengungkapan dengan kinerja perusahaan juga diteliti oleh beberapa peneliti. Peters dan Romi (2014), dalam studi tentang pengungkapan sosial di antara perusahaan, menawarkan satu kemungkinan alasan. Hubungan antara pengungkapan dan kinerja belum sepenuhnya dieksplorasi karena pengungkapan seringkali bersifat sukarela. Penelitian tersebut juga memberikan beberapa bukti pengungkapan kepatuhan lingkungan dan kinerja perusahaan. Huang dan Kung (2010) mengklasifikasikan perusahaan sampel ke dalam beberapa kategori, tergantung pada tingkat kepatuhan perusahaan terhadap kebijakan lingkungan dan deskripsi komitmen lingkungan perusahaan. Kinerja keuangan diukur dengan menggunakan laba bersih dibagi dengan total aset perusahaan. Pengukuran kebijakan lingkungan dan komitmen diperoleh melalui survei dari perusahaan. Hasil penelitian menunjukkan perbedaan yang signifikan antara kinerja dan kebijakan dan komitmen lingkungan. Perusahaan yang diklasifikasikan sebagai perusahaan berkinerja menengah memiliki tingkat kebijakan dan komitmen lingkungan yang paling tinggi. Hasil penelitian ini menunjukkan bahwa hubungan antara kinerja perusahaan dan kebijakan lingkungan dan atau komitmen tidak linier seperti diasumsikan dalam penelitian sebelumnya.

Perusahaan melakukan pengungkapan lingkungan dengan tujuan untuk memberikan informasi kepada para pemangku kepentingan mengenai kegiatan perusahaan. Selain itu, pegungkapan lingkungan juga berguna untuk mewujudkan serta meningkatkan akuntabilitas perusahaan dengan anggapan bahwa terdapat kontrak sosial antara perusahaan dengan masyarakat. Pengungkapan lingkungan menunjukkan bahwa perusahaan memberikan sinyal kepada para pemangku kepentingan bahwa mereka memiliki kinerja lingkungan yang baik. Diharapkan, melalui pengungkapan lingkungan, akan lebih banyak pihak di luar perusahaan yang mengetahui seberapa besar kinerja lingkungan yang dilakukan oleh perusahaan. Hal ini dianggap dan diharapkan mampu meningkatkan nilai serta image perusahaan dan juga dapat menarik investor potensial yang memberikan perhatian lebih pada isuisu lingkungan. Penelitian tentang penyajian laporan kinerja lingkungan yang mengacu pada standar GRI telah banyak dilakukan. Hasil penelitian menunjukkan terdapat trend peningkatan penggunaan GRI dalam penyusunan laporan kinerja lingkungan karena adanya respon positif dari pemangku kepentingan atas penggunaan acuan tersebut (Tschopp dan Nastanski, 2014; Vigneau et al. 2015; Willis, 2003; Yadava dan Sinha, 2016). Oleh karena itu, penelitian ini bertujuan untuk menguji pengaruh kinerja lingkungan dan terhadap kinerja saham perusahaan publik di Indonesia yang terdaftar dalam Indeks SRI KEHATI dengan menggunakan metoda kuantitatif. Perusahaan publik yang menjadi sampel adalah perusahaan yang terdaftar di Bursa Efek Indonesia selama periode 2017-2019.

Kinerja lingkungan yang dilaksanakan oleh perusahaan dapat menjadi salah satu indikator seberapa baik tingkat pengelolaan lingkungan yang dilakukan oleh perusahaan. Kinerja lingkungan tersebut salah satunya dapat diukur melalui pelaporan kinerja lingkungan yang mengacu pada Standard GRI Seri 300. Standard GRI Seri 300 terdiri dari 8 (delapan) komponen, 
yaitu seri 301 Material, seri 302 Energi, seri 303 Air dan Efluen, seri 304 Keanekaragaman Hayati, seri 305 Emisi, seri 306 Air limbah dan Limbah, seri 307 Kepatuhan Lingkungan dan seri 308 Kepatuhan Pemasok. Kedelapan komponen tersebut terdiri dari 30 komponen pernyataan pada Standard GRI Seri 300.

\section{METODE PENELITIAN}

Penelitian ini adalah penelitian kuantitatif dengan variabel independen berupa kinerja lingkungan dan variabel dependen kinerja saham. Objek penelitian ini adalah laporan kinerja lingkungan perusahaan, yang diperoleh dari laporan keberlanjutan atau laporan tahunan dari perusahaan-perusahaan di Bursa Efek Indonesia (BEI) yang memenuhi kriteria pengambilan sampel. Periode penelitian dari penelitian ini adalah tahun 2017-2019. Sumber data yang digunakan dalam penelitian ini adalah sebagai berikut: Laporan keuangan perusahaan periode 2017-2019 yang diambil dari website BEI yaitu www.idx.com; Laporan keberlanjutan (sustainability report) periode 20172019 yang diambil dari publikasi laporan keberlanjutan di website masing-masing perusahaan sampel dan atau laporan tahunan (annual report) perusahaan yang menjadi sample penelitian; Perusahaan terdaftar di Indeks SRI KEHATI di www.idx.com.

Populasi yang menjadi objek pada penelitian ini adalah semua perusahaan yang terdaftar di BEI pada periode 2017-2019. Periode ini diambil dengan mempertimbangkan diterbitkannya Standard GRI Seri 300 yang berlaku per 1 Juli 2018, dengan mendorong adopsi standar yang lebih awal. Metoda pengambilan sampel yang digunakan pada penelitian ini adalah purposive sampling, berdasarkan kriteria yaitu Perusahaan yang menerbitkan laporan keuangan di BEI pada periode 2017-2019; Perusahaan yang melakukan pengungkapan lingkungan sesuai dengan Standard GRI Seri 300 pada laporan keberlanjutan dan atau laporan tahunan; Perusahaan terdaftar di Indeks SRI KEHATI di www.idx.com secara berturut-turut dari tahun 20172019.

Total sampel dalam penelitian ini adalah 22 perusahaan dengan tahun pengamatan dari 2017-2019. Oleh karena itu, terdapat 66 laporan kinerja yang menjadi objek pengamatan dan disajikan dalam bentuk panel data. Uji statistik yang digunakan dalam penelitian ini adalah uji regresi pooled data, setelah sebelumnya dilakukan pengujian asumsi klasik. Adapun model penelitian ini dapat ditampilkan dalam model berikut ini $(\alpha=5 \%)$ :

KinerjaSaham $($ CAR $)=\alpha+\beta 1$ Material $+\beta_{2}$ Energi $+\beta 3$ AirEfluen $+\beta 4$ Hayati $+\beta 5$ Emisi $+\beta 6$ Limbah $+\beta 7$ Patuhlingkungan $+\beta 8$ Patuhpemasok $+\varepsilon$

Pengukuran variabel kinerja lingkungan dalam penelitian ini didasarkan pada luas pengungkapan lingkungan perusahaan yang diukur melalui jumlah pengungkapan lingkungan yang dilakukan oleh perusahaan sesuai dengan Standard GRI Seri 300 pada laporan keberlanjutan atau laporan tahunan yang diperoleh dari www.globalreporting.org. Pengukuran dilakukan dengan prosedur dikotomi, yaitu pemberian skor 1 untuk tiap pengungkapan lingkungan yang dilakukan perusahaan dan pemberian skor 0 jika perusahaan tidak melakukan pengungkapan. Jumlah item pengungkapan lingkungan yang terdapat dalam Standard GRI Seri 300 adalah 30 item pengungkapan yang terkait dengan topik lingkungan. Ketiga puluh pengungkapan tersebut terdiri dari komponen:

a. Material (tiga subkomponen: materials used by weight or volume; recycled input material used; dan reclaimed products and their packaging materials).

b. Energi (lima subkomponen: energy consumption within the organization; energy consumption outside of the organization; energy intensity; reduction of energy consumption; dan reduction in energy requirements of products and services).

c. Air dan Efluen (empat subkomponen: interactions with water as a shared resource; management of water discharge-related impacts; water withdrawal and water discharge dan water consumption).

d. Keanekaragaman Hayati (empat subkomponen: operational sites owned, managed in, or adjacent to, protected areas and areas of high biodiversity value outside protected areas; significant impacts of activities, products, and services on biodiversity; dan habitats protected or restored and IUCN red list species).

e. Emisi (enam subkomponen: direct (scope 1) $G H G$ emissions; energy indirect (scope 2) GHG emissions; other indirect (scope 3) GHG emissions; GHG emissions intensity; reduction of GHG emissions; dan emissions of ozone-depleting substances (ODS) and other significant air emissions).

f. Limbah (lima subkomponen: water discharge by quality and destination; waste by type and disposal method; significant spills; transport of hazardous waste; dan water bodies affected by water discharges 
and/or runoff).

g. Kepatuhan Lingkungan (satu subkomponen: non-compliance with environmental laws and regulatuons).

h. Kepatuhan Pemasok terhadap Isu Lingkungan (dua subkomponen:newsuppliers thatwerescreened using environmental criteria; dan negative environmental impacts in the suppy chain and actions taken).

Kinerja saham dalam penelitian ini diukur dengan menggunakan Cummulative Abnormal Return (CAR). CAR diambil pada seputar tanggal pengumuman laporan kinerja lingkungan perusahaan yang menjadi sampel dalam penelitian ini. Data terkait dengan CAR diambil dari laporan keuangan setiap perusahaan sampel.

Dalam beberapa penelitian (Chen et al. 2014; Connelly dan Limpaphayom, 2004; Huang dan Kung, 2010; Nurhayati et al. 2016) dihipotesiskan bahwa terdapat hubungan yang signifikan antara pelaporan lingkungan dan kinerja perusahaan. Namun, hubungannya tidak sama antara yang melakukan pelaporan secara singkat dengan yang melakukan pelaporan dalam jangka panjang. Dalam jangka pendek, perusahaan menderita biaya tinggi dan berkurangnya daya saing sebagai akibat dari peningkatan biaya perlindungan lingkungan. Peningkatan biaya pada gilirannya mengarah pada hubungan negatif antara kinerja lingkungan dan kinerja akuntansi (saat ini). Investor mendukung perusahaan yang melaporkan kegiatan yang bertanggung jawab terhadap lingkungan, karena dampak positif kegiatan lingkungan cenderung terwujud dalam jangka waktu yang lama.

Beberapa penelitian menyatakan peraturan lingkungan yang dirancang secara sistematis dapat memberikan hasil yang optimal (Wu et al. 2014; Yadava dan Sinha, 2016). Dengan kata lain, ada manfaat yang dapat diperoleh dengan memiliki standar lingkungan, tetapi standar tersebut harus mendorong daya saing jangka panjang dan berkelanjutan. Hal tersebut mengakibatkan timbulnya relasi yang positif pada regulasi yang tidak terlalu ketat, ketika peraturan lingkungan menguntungkan semua pihak yang berkepentingan, tetapi relasi tersebut tidak signifikan atau bahkan menjadi relasi yang negatif pada tingkat regulasi yang terlalu ketat. Adanya titik optimal mengandung makna bahwa pemerintah seharusnya tidak memberlakukan peraturan yang terlalu lunak atau terlalu ketat, karena hal tersebut terkait dengan return perusahaan di pasar modal pada jangka pendek maupun jangka panjang. Model return jangka pendek atau akuntansi menggunakan return aset sebagai ukuran return, sedangkan model return jangka panjang menggunakan return pasar sebagai ukuran return. Untuk setiap ukuran return, variabel pengungkapan lingkungan mengukur tingkat kinerja lingkungan dan atau kepatuhan yang diungkapkan oleh perusahaan.

Sementara itu, pengungkapan lingkungan diduga memiliki hubungan dengan nilai perusahaan. Apabila perusahaan melakukan pengelolaan biaya lingkungan dengan baik dan terstruktur serta memiliki kinerja lingkunganyangbaikdankemudianmengungkapkannya, maka hal tersebut mengindikasikan adanya manajemen yang berkualitas sehingga diharapkan perusahaan akan mendapat reaksi positif dari pasar. Dengan demikian, hipotesis dalam penelitian ini adalah kinerja lingkungan perusahaan berpengaruh terhadap kinerja saham perusahaan yang terdaftar di Indeks SRI KEHATI di BEI.

\section{HASIL}

\section{Hasil Uji Asumsi Klasik}

Sebelum dilakukan pengujian dengan menggunakan regresi, terlebih dahulu dilakukan pengujian asumsi klasik terhdap data. Uji asumsi klasik yang pertama adalah Uji Normalitas. Uji normalitas dilakukan dalam penelitian ini untuk mengetahui apakah residual berdistribusi normal. Dalam penelitian ini, peneliti menggunakan uji Kolmogorov-Smirnov. Berdasarkan pada hasil uji normalitas di Tabel 1, nilai dari Asymp. Sig. (2-tailed) adalah sebesar 0,310. Nilai 0,310 lebih besar dari nilai signifikansi 0,05 sehingga menandakan bahwa residual berdistribusi normal. Oleh karena itu, data dapat diuji dengan menggunakan alat uji regresi.

Uji autokolerasi juga dilakukan dalam penelitian ini untuk mengetahui apakah pada model regresi terdapat kolerasi antara kesalahan pengganggu pada periode sebelumnya atau $\mathrm{t}-1$. Berikut adalah hasil dari pengujian autokolerasi yang ditampilkan pada Tabel 2. Nilai yang diperoleh dari hasil uji $Z$ adalah sebesar 0,084. Dikarenakan nilai pada Asymp. Sig. (2-tailed) menunjukkan angka 0,084 yang nilainya lebih dari 0,05 maka data dalam penelitian ini (Abnormal Return sebagai pengukur kinerja saham) tidak terjadi gejala autokolerasi. 
Uji selanjutnya adalah uji multikolinearitas untuk mengetahui apakah dalam sebuah model regresi terdapat adanya hubungan atau korelasi antar variabel independen. Berikut adalah hasil dari pengujian multikolinearitas yang ditampilkan pada Tabel 3 . Adanya multikolinearitas dapat diketahui melalui nilai VIF dari variabel yang digunakan dalam penelitian. Berdasar pada data di atas, nilai VIF dari seluruh variabel adalah kurang dari 10 sehingga dapat disimpulkan bahwa tidak ada multikolinearitas.

Uji asumsi klasik yang terakhir adalah uji yang digunakan untuk mengetahui apakah dalam sebuah model regresi terdapat ketidaksamaan varians residual dari suatu pengamatan ke pengamatan yang lain berupa uji heteroskedastisitas. Pada penelitian ini, peneliti menggunakan metode Park Glejser untuk mengetahui apakah terdapat gejala heteroskedastisitas. Nilai signifikansi menjadi acuan untuk menentukan ada tidaknya heterokedastisitas. Jika nilai signifikansinya lebih dari 0,05 maka tidak terjadi gejala heteroskedastisitas, begitu pula sebaliknya. Pada Tabel 4 menunjukkan seluruh variabel independen pada penelitian ini memiliki nilai signifikansi yang semuanya lebih dari 0,05 sehingga dapat disimpulkan bahwa tidak terjadi gejala heteroskedastisitas.

\section{Hasil Pengujian Statistik}

Nilai koefisien determinasi dalam penelitian ini digunakan untuk mengetahui besarnya pengaruh variabel independen terhadap variabel dependen. Nilai dari koefisien determinasi (R Square) adalah 0,373. Selain itu, pada Tabel 5 juga terdapat nilai Adjusted $\mathrm{R}$ Square atau nilai R Square disesuaikan. Berbeda dengan nilai R Square, nilai Adjusted R Square yang dihasilkan berdasarkan Tabel 5 adalah sebesar 0,285.

Sementara itu, uji F dilakukan untuk menguji ketepatan model. Tabel 5 menunjukkan bahwa nilai $\mathrm{F}$ sebesar 4,243 dengan nilai signifikansi sebesar 0,000 , sehingga dapat disimpulkan model layak dalam memprediksi pengaruh variabel independen terhadap variabel dependen. Hal tersebut karena variabel material, energi, air dan efluen, keanekaragaman hayati, emisi, limbah, kepatuhan lingkungan dan kepatuhan pemasok dalam penelitian ini memiliki pengaruh yang simultan dan signifikan terhadap variabel CAR.

Tabel 1. Hasil Uji Normalitas

\begin{tabular}{lccc}
\hline Variabel & Kolmogorov- Smirnov & Asymp. Sig. (2-tailed) & Keterangan \\
\hline Unstandardized Residual & 0,079 & 0,310 & Normal \\
\hline
\end{tabular}

Tabel 2. Hasil Uji Autokolerasi

\begin{tabular}{lccc}
\hline Variabel & $\mathrm{Z}$ & Asymp. Sig. (2-tailed) & Keterangan \\
\hline Unstandardized Residual & 0,084 & 0,220 & Tidak terjadi Autokolerasi \\
\hline
\end{tabular}

Tabel 3. Uji multikolinearitas variabel kinerja lingkungan

\begin{tabular}{lcccccccc}
\hline Keterangan & Material & Energi & AirEfluen & Hayati & Emisi & Limbah & $\begin{array}{c}\text { Patuh } \\
\text { Linkungan }\end{array}$ & $\begin{array}{c}\text { Patuh } \\
\text { Pemasok }\end{array}$ \\
\hline Tolerance & 0,740 & 0,779 & 0,873 & 0,913 & 0,915 & 0,872 & 0,968 & 0,872 \\
VIF & 1,351 & 1,283 & 1,146 & 1,095 & 1,093 & 1,147 & 1,033 & 1,146 \\
Keterangan & & & \multicolumn{7}{c}{ Tidak terjadi mutikolinearitas } \\
\hline
\end{tabular}

Tabel 4. Uji Heterokedastisitas

\begin{tabular}{lcccccccc}
\hline Keterangan & Material & Energi & AirEfluen & Hayati & Emisi & Limbah & $\begin{array}{c}\text { Patuh } \\
\text { Linkungan }\end{array}$ & $\begin{array}{c}\text { Patuh } \\
\text { Pemasok }\end{array}$ \\
\hline $\mathrm{t}$ & 2,321 & 2,112 & 1,321 & $-2,111$ & 2,987 & 1,956 & 1,789 & 2,786 \\
sig & 0,220 & 0,324 & 0,221 & 0,341 & 0,225 & 0,332 & 0,223 & 0,112 \\
Keterangan & & \multicolumn{7}{c}{ Tidak terjadi heterokedastisitas } \\
\hline
\end{tabular}




\section{Uji Parsial (Uji t)}

Uji t merupakan uji yang digunakan untuk mengetahui signifikansi dari pengaruh variabel independen secara individu terhadap variabel dependen. Berikut adalah hasil dari uji parsial yang dilakukan yang ditampilkan pada Tabel 6. Pada tabel tersebut ditunjukkan empat variabel independent yang memiliki pengaruh positif dan signifikan terhadap variabel dependen. Adapun model regresi berdasarkan hasil pengujian yang dilakukan adalah sebagai berikut.

\section{CAR $=-0.538+1.048$ Material +0.054 Energi + 0.956AirEfluen +0.212 Hayati +0.977 Emisi + 1.526Limbah + 4.167PatuhLingkungan + 0.393 PatuhPemasok $+\varepsilon$}

Hasil menunjukkan bahwa dari delapan variabel yang diteliti, seluruh variabel (material, energi, air dan efluen, hayati, emisi, limbah, kepatuhan lingkungan, dan kepatuhan pemasok) memiliki pengaruh positif terhadap variabel dependen CAR. Hal tersebut dilihat dari nilai $\mathrm{t}$ yang bernilai positif untuk kedelapan variabel tersebut. Hipotesis dalam penelitian ini menyatakan bahwa variabel kinerja lingkungan berpengaruh terhadap kinerja saham, sehingga dapat disimpulkan bahwa hasil penelitian ini mendukung hipotesis dalam penelitian ini. Apabila dilihat dari nilai signifikansinya, variabel energi, hayati, limbah dan kepatuhan lingkungan memiliki nilai signifikansi di bawah 5\% sehingga dapat disimpulkan bahwa keempat variabel tersebut berpengaruh secara signifikan terhadap variabel dependen CAR.

Hasil pengujian secara parsial untuk komponen pengungkapan material yang dilakukan menunjukkan hasil nilai t hitung sebesar 1,048 dan nilai signifikansi sebesar 0,299. Oleh karena itu, dapat disimpulkan bahwa perusahaan dengan pengungkapan GRI komponen material yang lebih baik memiliki pengaruh yang positif namun secara statistik tidak signifikan. Nilai signifikansi yang dihasilkan melebihi taraf signifikansi yang diterapkan, yaitu $0,299>0,05$.

Hasil pengujian parsial untuk komponen pengungkapan energi yang dilakukan menunjukkan hasil nilai t hitung sebesar 0,054 dan nilai signifikansi sebesar 0,047. Oleh karena itu, dapat disimpulkan bahwa perusahaan dengan pengungkapan GRI komponen energi yang lebih baik memiliki pengaruh yang positif dan secara statistik signifikan. Nilai signifikansi yang dihasilkan lebih rendah dari taraf signifikansi yang diterapkan, yaitu $0,047<0,05$.

Hasil pengujian parsial yang dilakukan untuk komponen pengungkapan air dan efluen menunjukkan hasil nilai t hitung sebesar 0,956 dan nilai signifikansi sebesar 0,443. Oleh karena itu, dapat disimpulkan bahwa perusahaan dengan pengungkapan GRI komponen air dan efluen yang lebih baik memiliki pengaruh yang positif namun secara statistik tidak signifikan. Nilai signifikansi yang dihasilkan melebihi taraf signifikansi yang diterapkan, yaitu $0,443<0,05$.

Hasil pengujian parsial untuk komponen pengungkapan keanekaragaman hayati yang dilakukan menunjukkan hasil nilai t hitung sebesar 0,222 dan nilai signifikansi sebesar 0,033. Oleh karena itu, dapat disimpulkan bahwa perusahaan dengan pengungkapan GRI komponen keanekaragaman hayati yang lebih baik memiliki pengaruh yang positif dan secara statistik signifikan. Nilai signifikansi yang dihasilkan lebih rendah taraf signifikansi yang diterapkan, yaitu 0,033 $<0,05$.

Tabel 5. Koefisien Determinasi (R2) dan nilai F

\begin{tabular}{ll}
\hline Keterangan & Nilai \\
\hline R & 0,611 \\
R Square & 0,373 \\
Adj. R Square & 0,285 \\
F & 4,243 \\
Sig. & 0,000 \\
\hline
\end{tabular}

Tabel 6. Hasil Regresi Menggunakan Uji t

\begin{tabular}{lcc}
\hline Variabel & $\mathrm{t}$ & Sig. \\
\hline (Constant) &,- 538 &, 592 \\
Material & 1,048 &, 299 \\
Energi &, 054 &, $047^{*}$ \\
AirEfluen &, 956 &, 443 \\
Hayati &, 222 &, $033^{*}$ \\
Emisi &, 977 &, 333 \\
Limbah & 1,526 &, $002^{*}$ \\
PatuhLink & 4,167 &, $000^{*}$ \\
PatuhPasok &, 393 &, 696 \\
\hline
\end{tabular}

Dependent variabel CAR; * signifikan pada $\alpha 5 \%$ 
Hasil pengujian parsial yang dilakukan untuk pengungkapan komponen emisi menunjukkan hasil nilai thitung sebesar 0,977 dan nilai signifikansi sebesar 0,333 . Oleh karena itu, dapat disimpulkan bahwa perusahaan dengan pengungkapan GRI komponen emisi yang lebih baik memiliki pengaruh yang positif namun secara statistik tidak signifikan. Nilai signifikansi yang dihasilkan melebihi taraf signifikansi yang diterapkan, yaitu $0,333>0,05$.

Hasil pengujian parsial yang dilakukan untuk komponen pengungkapan air dan air limbah menunjukkan hasil nilai thitung sebesar 1,526 dan nilai signifikansi sebesar 0,002. Oleh karena itu, dapat disimpulkan bahwa perusahaan dengan pengungkapan GRI komponen air dan air limbah yang lebih baik memiliki pengaruh yang positif dan secara statistik signifikan. Nilai signifikansi yang dihasilkan dibawah taraf signifikansi yang diterapkan, yaitu $0,002<0,05$.

Hasil pengujian parsial yang dilakukan untuk komponen pengungkapan kepatuhan lingkungan menunjukkan hasil nilai t hitung sebesar 4,167 dan nilai signifikansi sebesar 0,000 . Oleh karena itu, dapat disimpulkan bahwa perusahaan dengan pengungkapan GRI komponen kepatuhan lingkungan yang lebih baik memiliki pengaruh yang positif dan secara statistik signifikan. Nilai signifikansi yang dihasilkan lebih rendah taraf signifikansi yang diterapkan, yaitu 0,000 $<0,05$.

Hasil pengujian parsial terhadap komponen pengungkapan kepatuhan kepada pemasok yang dilakukan menunjukkan hasil nilai t hitung sebesar 0,393 dan nilai signifikansi sebesar 0,696 . Oleh karena itu, dapat disimpulkan bahwa perusahaan dengan pengungkapan GRI komponen kepatuhan pemasokyang lebih baik memiliki pengaruh yang positif dan namun secara statistik tidak signifikan. Nilai signifikansi yang dihasilkan lebih besar dari taraf signifikansi yang diterapkan, yaitu 0,696>0,05.

Pelaporan kinerja lingkungan di Indonesia bagi perusahaan publik merupakan pelaporan yang bersifat sukarela, dan bukan pelaporan yang bersifat wajib seperti halnya pelaporan kinerja keuangan. Pelaporan kinerja lingkungan juga belum memiliki standar yang wajib untuk diikuti oleh perusahaan-perusahaan yang secara sukarela menyusun laporan tersebut. Di Indonesia dan banyak negara yang lain di dunia, konsep serta format pelaporan kinerja lingkungan banyak mengacu kepada konsep dan format yang disusun oleh Global Reporting Initiative (GRI). Selain itu, di Indonesia perusahaan publik yang memiliki kewajiban untuk menyampaikan kinerja lingkungan melalui sustainability reporting-nya adalah perusahaan yang termasuk ke dalam kategori industri perbankan, dibawah aturan Otoritas Jasa Keuangan (OJK) No. 51/POJK.03/2017. Hal tersebut belum sepenuhnya diikuti oleh perusahaan publik yang ada di luar industri perbankan. Oleh karena itu, kesadaran perusahaan publik di Indonesia untuk menyampaikan laporan kinerja lingkungan yang sesuai dengan standar menjadi hal yang menarik perhatian. Hasil penelitian ini menunjukkan bahwa dari delapan variabel yang diteliti, seluruh variabel (material, energi, efluen, hayati, emisi, limbah, kepatuhan lingkungan, dan kepatuhan pemasok) memiliki pengaruh positif terhadap variabel dependen CAR. Hal tersebut dilihat dari nilai $t$ yang bernilai positif untuk kedelapan variabel tersebut.

Apabila dilihat dari nilai signifikansinya, variabel energi, hayati, limbah dan kepatuhan lingkungan memiliki nilai signifikansi di bawah $5 \%$ sehingga dapat disimpulkan bahwa keempat variabel tersebut berpengaruh secara signifikan terhadap variabel kinerja saham yang diukur dengan CAR.

Hasil penelitian ini mendukung beberapa penelitian sebelumnya (Vigneau et al. 2015; Yadava dan Sinha, 2016) yang memberikan motivasi lain bagi perusahaan untuk mengungkapkan keuangan dan informasi nonkeuangan dengan menyatakan bahwa agar dalam aktivitas operasinya yang terkait dengan lingkungan, perusahaan harus mengembangkan kesesuaian antara dampak sosial mereka dengan kegiatan dengan normanorma perilaku yang dapat diterima dalam sistem sosial yang lebih besar. Tanggung jawab sosial perusahaan yang disajikan dalam laporan kinerja lingkungan juga bisa menjadi cara efektif untuk mengurangi perhatian politik atau meminimalkan eksposur politik dari perusahaan besar. Selain itu, sejak beberapa dekade terakhir, para pemangku kepentingan mengajukan permintaan informasi yang berkaitan dengan berbagai aktivitas perusahaan yang meningkat secara massif. Para pemangku kepentingan ini mengharapkan perusahaan untuk mengungkapkan tidak hanya informasi keuangan saja tetapi juga informasi yang berkaitan terhadap aktivitas yang dilakukan terhadap masyarakat dan lingkungan (Reynolds dan Yuthas, 2008; Tschopp dan Huefner, 2015; Tschopp dan Nastanski, 2014). Selain itu, perusahaan secara tidak langsung juga memiliki 
ketergantungan terhadap pemangku kepentingan termasuk didalamnya masyarakat yang berharap kebutuhannya dapat terpenuhi. Oleh karena itu, dari perspektif teori pemangku kepentingan, perusahaan dapat dievaluasi melalui laporan keberlanjutannya yang mencakup laporan kinerja lingkungan dalam hal memenuhi tuntutan berbagai macam pemangku kepentingan (Baxi dan Ray, 2009; Pérez et al. 2015). Beberapa penelitian di Indonesia juga menunjukkan hasil adanya upaya positif dari pihak manajemen untuk melakukan pengelolaan lingkungan yang baik terkait dengan aktivitas operasi perusahaan yang berkelanjutan (Bahara et al. 2015; Wardhani et al. 2018).

Hasil penelitian ini bertentangan dengan hasil penelitian yang dilakukan oleh Matsumura et al. (2014) dan Willis (2003) dimana secara global perusahaan menghadapi tekanan terus menerus dari berbagai kelompok pemangku kepentingan sehingga hal tersebut memicu rendahnya lingkup pengungkapan lingkungan yang dilakukan oleh perusahaan. Perusahaan yang berkembang dan terutama yang berkontribusi terhadap kerusakan lingkungan memiliki kecenderungan untuk tidak mengungkapkan kinerja lingkungannya secara lengkap dengan motif menghindari tekanan pemangku kepentingan di luar perusahaan, sementara dalam penelitian ini, sampel diambil dari perusahaan yang termasuk ke dalam indeks SRI KEHATI yang memiliki kepatuhan yang cukup baik terhadap standar yang mengatur tentang pengungkapan lingkungan.

\section{Implikasi Manajerial}

Bukti dalam penelitian ini memiliki implikasi agar perusahaan memperhatikan kinerja lingkungannya sebagai salah satu upaya untuk memperoleh nilai perusahaan yang diinginkan. Investor juga perlu mulai memberikan porsi perhatian terhadap kinerja perusahaan publik dengan menggunakan laporan kinerja lingkungan sebagai salah satu acuan selain kinerja fundamental dan teknikal dalam penentuan investasi di pasar modal. Investor perlu lebih jeli dalam menanamkan investasinya pada perusahaan yang memiliki kepedulian terhadap lingkungan dan berupaya untuk menjaga kelestarian lingkungan dimana perusahaan tersebut beraktivitas dan beroperasi untuk mencapai kepentingan bersama. Namun demikian, sejalan dengan hasil penelitian sebelumnya (Tschopp dan Nastanski, 2014; Vigneau et al. 2015), kepatuhan perusahaan yang terlalu tinggi terhadap standar kinerja lingkungan akan menimbulkan trade off yang kurang menguntungkan baik dari sisi biaya investasi maupun biaya politis. Oleh karena itu, perusahaan tetap dimotivasi untuk menjaga kelestarian lingkungan dan melakukan pengelolaan lingkungan dengan baik, dengan tetap memperhatikan keseimbangan dengan faktor finansial perusahaan. Pelaporan kinerja lingkungan juga diperlukan agar pemangku kepentingan, khususnya investor, mendapatkan informasi yang cukup dan komprehensif terkait dengan pengelolaan lingkungan karena dapat meningkatkan nilai perusahaan. Penggunaan standar pelaporan kinerja lingkungan dapat dilakukan dengan mengacu pada standar yang telah berlaku umum, dengan menggunakan item-item yang tertera di dalam standar tersebut sebagai dasar penyusunan narasi laporan kinerja lingkungan.

\section{KESIMPULAN DAN SARAN}

\section{Kesimpulan}

Hasil penelitian menunjukkan bahwa perusahaan dengan pengungkapan GRI yang lebih baik memiliki pengaruh yang positif terhadap kinerja saham. Hal tersebut dimungkinkan karena perusahaan yang berkinerja baik memiliki dana lebih untuk diinvestasikan pada aktivitas yang mendukung kelestarian lingkungan. Kesadaran perusahaan untuk tetap menjaga lingkungan dan melaporkannya ke dalam laporan kinerja lingkungan membawa dampak positif berupa respon pemangku kepentingan, dalam hal ini investor untuk memberikan nilai yang baik bagi perusahaan.

\section{Saran}

Keterbatasan penelitian ini hanya berfokus pada kinerja lingkungan jangka pendek sehingga perlu ditambahkan penggunaan variabel lain sebagai kontrol variabel yang akan mempengaruhi kinerja lingkungan dalam jangka panjang, seperti variabel rasio keuangan dan biaya riset dan pengembangan yang terkait dengan biaya lingkungan pada perusahaan sampel. Penelitian lanjutan dapat dikembangkan dengan menggunakan metoda eksperimen terhadap investor maupun investor potensial terkait dengan keputusan yang mereka buat apabila pelaporan kinerja perusahaan terdiri dari laporan yang terintegrasi, baik laporan kinerja keuangan maupun laporan kinerja lingkungan. 


\section{DAFTAR PUSTAKA}

Bahara R, Marimin M, Arkeman Y. 2015. Perbaikan produktivitas hijau pada proses produksi susu bubuk dewasa. Jurnal Aplikasi Bisnis Dan Manajemen 1(2): 65-74. https://doi. org/10.17358/JABM.1.2.65.

Baxi CV, Ray RS. 2009. Corporate social dan environmental disclosures dan reporting. Indian Journal of Industrial Relation 44(3): 355-375.

Cai L, Cui J, Jo H. 2016. Corporate environmental responsibility and firm risk. Journal of Business Ethics 139(3): 563-594. https://doi.org/10.1007/ s10551-015-2630-4.

Chen JC, Cho CH, Patten DM. 2014. Initiating disclosure of environmental liability information: an empirical analysis of firm choice. Journal of Business Ethics 125(4): 681-692. https://doi. org/10.1007/s10551-013-1939-0.

Chen $\mathrm{Y}$ et al. 2015. Linking market orientation and environmental performance: the influence of environmental strategy, employee's environmental involvement, and environmental product quality. Journal of Business Ethics, 127(2), 479-500. https://doi.org/10.1007/ s10551-014-2059-1.

Comyns B. 2016. Determinants of GHG reporting: an analysis of global oil and gas companies. Journal of Business Ethics 136(2): 349-369. https://doi. org/10.1007/s10551-014-2517-9.

Connelly JT, Limpaphayom P. 2004. Environmental reporting and firm performance: evidence from Thailand. The Journal of Corporate Citizenship 13: 137-149. https://doi.org/10.9774/ GLEAF.4700.2004.sp.000015.

Elsayed K. 2006. Reexamining the expected effect of available resources and firm size on firm environmental orientation: an empirical study of UK Firms. Journal of Business Ethics 65(3): 297-308. https://doi.org/10.1007/s10551-0066402-z.

Huang CL, Kung FH. 2010. Drivers of environmental disclosure and stakeholder expectation: evidence from Taiwan. Journal of Business Ethics 96(3): 435-451. https://doi.org/10.1007/s10551-0100476-3.

Kathy Rao K, Tilt CA, Lester LH. 2012. Corporate governance and environmental reporting: An Australian study. Corporate Governance: The International Journal of Business in Society 12(2): 143-163. https://doi. org/10.1108/14720701211214052.

Li W, Lu X. 2016. Institutional interest, ownership type, and environmental capital expenditures: evidence from the most polluting chinese listed firms. Journal of Business Ethics 138(3): 459-476. https://doi.org/10.1007/s10551-0152616-2.

Matsumura EM, Prakash R, Vera-Muñoz SC. 2014. Firm-value effects of carbon emissions and carbon disclosures. The Accounting Review 89(2): $\quad$ 695-724.https://doi.org/10.2308/accr50629 .

Nurhayati R et al. 2016. Factors determining social and environmental reporting by Indian textile and apparel firms: a test of legitimacy theory. Social Responsibility Journal 12(1): 167-189. https://doi.org/10.1108/SRJ-06-2013-0074.

Perez-Batres LA, Miller VV, Pisani M J. 2010. CSR, sustainability and the meaning of global reporting for latin american corporations. Journal of Business Ethics 91: 193-209. https:// doi.org/10.1007/s10551-010-0614-y.

Pérez A et al. C. 2015. Corporate Reputation in the spanish context: an interaction between reporting to stakeholders and industry. Journal of Business Ethics 129(3): 733-746. https://doi.org/10.1007/ s10551-014-2199-3.

Peters GF, Romi, AM. 2014. Does the voluntary adoption of corporate governance mechanisms improve environmental risk disclosures? evidence from greenhouse gas emission accounting. Journal of Business Ethics 125(4): 637-666.https://doi. org/10.1007/s10551-013-1886-9.

Reynolds MA., Yuthas K. 2008. Moral discourse and corporate social responsibility reporting. Journal of Business Ethics 78(1/2): 47-64. https://doi. org/10.1007/s10551-006-9316-x.

Shaukat A, Qiu Y, Trojanowski G. 2016. Board attributes, corporate social responsibility strategy, and corporate environmental and social performance. Journal of Business Ethics 135(3): 569-585. https://doi.org/10.1007/s10551-0142460-9.

Tschopp D, Huefner RJ. 2015. Comparing the evolution of csr reporting to that of financial reporting. Journal of Business Ethics 127(3): 565-577. https://doi.org/10.1007/s10551-014-2054-6.

Tschopp D, Nastanski M. 2014. The harmonization and convergence of corporate social responsibility 
reporting standards. Journal of Business Ethics 125(1): 147-162. https://doi.org/10.1007/ s10551-013-1906-9.

Vigneau L, Humphreys M, Moon, J. 2015. How do firms comply with international sustainability standards? processes and consequences of adopting the global reporting initiative. Journal of Business Ethics 131(2): 469-486. https://doi. org/10.1007/s10551-014-2278-5.

Wardhani M, Suharjo B, Djohar S. 2018. Elemenelemen sistem manajemen lingkungan keselamatan dan kesehatan kerja (SMLK3) untuk Bisnis Berkelanjutan. Jurnal Aplikasi Bisnis Dan Manajemen 4(1): 119-128. https:// doi.org/10.17358/jabm.4.1.119.
Willis A. 2003. The role of the global reporting initiative's sustainability reporting guidelines in the social screening of investm. Journal of Business Ethics 43(3): 233-237. https://doi. org/10.1023/A:1022958618391.

Wu Q, He Q, Duan Y. 2014. Dynamic capabilities for CSR management: towards identifying common processes. Society and Business Review 9(3): 276-297. https://doi.org/10.1108/SBR-01-20130010.

Yadava RN, Sinha B. 2016. Scoring Sustainability Reports Using GRI 2011 guidelines for assessing environmental, economic, and social dimensions of leading public and private indian companies. Journal of Business Ethics 138(3): 549-558. https://doi.org/10.1007/s10551-015-2597-1. 